
\title{
$\begin{array}{ll}\text { Research Square } & \begin{array}{l}\text { Preprints are preliminary reports that have not undergone peer review. } \\ \text { They should not be considered conclusive, used to inform clinical practice, } \\ \text { or referenced by the media as validated information. }\end{array}\end{array}$
}

\section{Sterilisation of Wort from Sugarcane Molasses by Electron Beam for Bioethanol Production}

\author{
Rubens Perez Calegari ( $\sim$ rubenscalegari@live.com) \\ Universidade de Sao Paulo Centro de Energia Nuclear na Agricultura https://orcid.org/0000-0002-9929-4736 \\ Eric Alberto Silva \\ IPEN: Instituto de Pesquisas Energeticas e Nucleares \\ Marcelo Pêgo Gomes \\ ESALQ-USP: Universidade de Sao Paulo Escola Superior de Agricultura Luiz de Queiroz \\ Ana Paula Maria Silva \\ ESALQ-USP: Universidade de Sao Paulo Escola Superior de Agricultura Luiz de Queiroz \\ Layna Amorim Mota \\ Universidade de Sao Paulo Centro de Energia Nuclear na Agricultura \\ Valter Arthur \\ Universidade de Sao Paulo Centro de Energia Nuclear na Agricultura \\ Antonio Sampaio Baptista \\ ESALQ-USP: Universidade de Sao Paulo Escola Superior de Agricultura Luiz de Queiroz
}

\section{Research Article}

Keywords: biofuel, electron accelerator, microbial contamination, radappertization, sucro-energetic industry.

Posted Date: April 21st, 2021

DOI: https://doi.org/10.21203/rs.3.rs-416562/v1

License: (c) (i) This work is licensed under a Creative Commons Attribution 4.0 International License. Read Full License 


\section{Abstract}

The presence of microbial contamination in the wort during the fermentation process results in damages of billions of dollars per year all around the world and promotes the industry dependence of chemicals and antibiotics to control the contamination. For these reasons, this study aimed to use the electron beam to sterilise wort from sugarcane molasses and investigate its bioethanol fermentation. Five treatments (T0 - T4) were carried out using ionizing doses of radiation through the electron accelerator: $(0,10,20,40$, and $80 \mathrm{kGy})$ and a positive control (T5-steam by autoclave) were performed. It was evaluated total mesophiles, total bacteria, sugars, phenolics, flavonoids, 5-hidroximetylfurfural, and Furfural. After the irradiation process, it was conducted an alcoholic fermentation assay using baker's yeast Saccharomyces cerevisiae. It was not observed inversion of sugars and formation of the inhibitory by-products flavonoids, furfural, and 5-hidroximetylfurfural, with exception of the phenolic compounds. Only T4 and T5 were able to sterilise the wort. However, T3 was able to eliminate $>99.99 \%$ of the microorganisms. In the fermentation T2 promoted the best ethanol yield and productivity among the irradiated treatments, evidencing the possibility of electron beam use in the wort treatment prior to fermentation which may allow a reduction in losses caused by microbial contamination, besides the possibility of promoting fermentation yield and productivity increase. The operation cost for applying the e-beam with a dose of $20 \mathrm{kGy}$ in a standard ethanol plant was estimated at US\$0.014 per $\mathrm{m}^{3}$ of wort.

\section{Introduction}

The worldwide demand for pollution reduction and uses of renewable energy has increased in recent years. At the same time, the need to make the best use of natural resources for highly efficient and sustainable biofuels. In this sense, the production of ethanol in Brazil is mainly based on the fermentation of sugarcane using the mesophilic yeast Saccharomyces cerevisiae (Ponce et al. 2016). The development of strategies to increase the efficiency and productivity of this microorganism are of great importance.

The efficiency of this biological agent in turning the sugar from the sugarcane juice or molasses into alcohol depends very much on the quality of the wort to be fermented. In industrial production, usually, this substrate is not sterilized prior to the fermentation process, which allows the entry of a large number of microbial contaminants in the process, which negatively affects efficiency and productivity (Amorim et al. 2011; Lopes et al. 2016).

Among the main losses caused by microbial contamination, we can cite formation of acids, increased flocculation, and reduction of yeast viability. The population of contaminating bacteria in fermentation can reach levels higher than $10^{7}$ cells $\mathrm{mL}^{-1}$, which can lead to a significant reduction in alcoholic

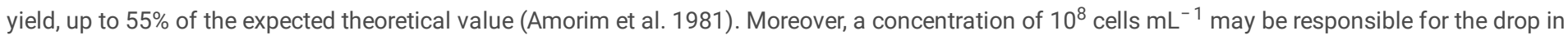
production of 10 to 30 thousand liters of ethanol in a distillery with a production capacity of one million liters per day (Amorim et al. 2011).

Commonly, the Brazilian sucro-energetic industries perform the acid treatment of yeast cream (Melle-Boinot process), which requires a large volume of sulfuric acid to reduce bacterial contamination (Basso et al. 2008; Costa et al. 2018; da Silva-Neto et al. 2020) This process is repeated countless times throughout the harvest, which last about 200 days a year (Brown et al. 2013). However, it is not completely efficient (Ceccato-Antonini 2018), may select resistant bacteria and, consequently promote the osmotic stress of the yeasts, and as a response, the yeasts produce greater amounts of glycerol, thereby reducing the yield of the fermentation (Basso et al. 2011). Furthermore, wild yeast strains rapidly contaminate the fermentation and after a few cycles, only the wild strains survive the acid treatment (Brown et al. 2013).

Another common way to control bacterial contamination in distilleries is the use of antibiotics, but drug resistance has been a limiting factor in the contamination control efficiency (Muthaiyan et al. 2011).

In this case, the use of sterilized wort for ethanol production may allow the use of selected yeast strains, with desirable and stable characteristics throughout the harvest season. Also, it is possible to reduce costs by eliminating or reducing the use of antibiotics, anti-foaming agents, acid treatment of yeast, and consumption of other inputs. It is also possible to reduce the time of recycling the yeasts in the industrial unit, which increases productivity over time. This means that the process could be optimized, costs reduced and productivity increased (Nolasco Jr 2010).

It should also be noted that some technologies, which are not usual today due to the lack of stability of the fermentation process to ethanol production, may become viable if working under aseptic conditions.

There are several methods that can be used for the sterilization of the wort, the substrate for alcoholic fermentation. However, in industrial plants such as the ethanol industry, where the volume of wort processed is huge, the traditional methods like conventional heat and chemical agents can be very costly. On the other hand, this industry has an energy surplus (Cervi et al. 2019), which can help to circumvent this problem, or rather, is self-sufficient in energy, and part of this energy can be used to generate a source to sterilize the wort.

In this way, Electron beam (e-beam), a type of Ionizing radiation (IR) is a quite effective technology for microorganisms inactivation and generally depends on the dose of radiation applied, where the logarithmic number of microorganisms decreases linearly with increasing dose (Sampa et al. 2007).

Besides, the doses used for sterilization do not produce radioisotopes or radioactive waste, demonstrates benefit over other irradiators such as Cobalt 60 (gamma irradiation), so its residue is the products derived from the radiolysis of water, such as water, hydrogen, and oxygen (Kochetkov et al. 1979; Schwarz 1981).

These radicals interact with the molecules and produce oxidation, reduction, dissociation, and degradation. Besides that, the IR can promote water radiolysis and consequently the destruction of microorganisms, insects, and other parasites (Molins 2001).

Page $2 / 15$ 
It should be noted that the main target of IR is the cells' genetic material DNA and/or RNA. The lesions promoted in the single DNA helix can result in mutation, but a large number of injuries may exceed the repair capacity of the microbial cell resulting in cell death (Stockwell et al. 2017). Other damages in crucial components of the cell such as proteins and lipids can be promoted by IR (Nie et al. 2012).

Withal, e-beam is a very safe method, it is cold, has a high Sterility Assurance Level (SAL), needs a short exposure time and the control parameter of the method is the dose applied. Furthermore, it is an on-off technology that operates with electric power and has a much higher dosing rate than other radiation technologies, such as gamma $(\mathrm{Y})$ and X-rays (Silindir and Özer 2009). One limitation of the technology is that it has low penetrating ability in materials (Lung et al. 2015). But the sugarcane wort can be irradiated in a thin liquid layer at controlled flow (Alcarde et al. 2001).

E-beam is an emerging technology that has been applied to industrial purposes, such as pharmaceutical and medical packing sterilisation, food disinfection and sterilisation (radappertization), and also to the treatment of water, municipal and industrial wastewater (Kurilova et al. 2015; Lung et al. 2015).

For these reasons, it is believed that the use of e-beam is a good strategy for the radappertization of the wort (commercial sterilisation) because allows it to be installed in the production line and to use part of the surplus energy of the industrial plant. Carrying in this way, greater efficiency in the processes of alcoholic fermentation.

Therefore, this study aimed to evaluate the application of the e-beam to control the contamination in wort from sugarcane molasses for alcoholic fermentation and to investigate the yield and productivity of alcoholic fermentation from wort treated with e-beam ionizing radiation.

\section{Material And Methods}

\section{Material}

The molasses of sugarcane used for the preparation of the wort to the alcoholic fermentation were obtained from a factory in Piracicaba city, São Paulo State, Brazil (22 $\left.43^{\prime} 31^{~ " S}, 47^{\circ} 38^{\prime} 57^{\prime \prime} \mathrm{W}\right)$, followed by physicochemical characterisation and stored in a freezer $\left(-20^{\circ} \mathrm{C}\right)$.

\section{Wort clarification}

The sugarcane molasses used for the preparation of the wort underwent the clarification process following Braga (2006) recommendations with the addition of 2,5 g of $\mathrm{NaH}_{2} \mathrm{PO}_{4} \mathrm{~L}^{-1}$ in boiled molasses. After the addition of the reagent, the molasses was autoclaved and held for 48 hours for further separation of the supernatant from the sedimented material.

At the end of the clarification step, the molasses with an initial concentration of $70{ }^{\circ}$ Brix $9628.75 \mathrm{~g} \mathrm{~L}^{-1}$ of total reducing sugars) was diluted with distilled water until the final concentration of $16,7^{\circ} \mathrm{Brix}\left(150 \mathrm{~g} \mathrm{l}^{-1}\right.$ of total reducing sugars) was obtained.

\section{Preparation of contaminating inoculum and inoculation}

For the preparation of the contaminant inoculum, a sample of 10 grams of soil from several points in a cane field was collected, to simulate the groups of contaminating microorganisms, normally, found in the process of alcoholic fermentation in sugarcane mills. This sample was mixed with $90 \mathrm{ml}$ of the clarified molasses, filtered using quantitative filter paper N.640, $125 \mathrm{~mm}$ (Hellma ${ }^{\circledR}$ ), and placed in a 250 ml Erlenmeyer flask. This Erlenmeyer was maintained at $30^{\circ} \mathrm{C}$, under stirring at 100 RPM, for 24 hours, using a shaker model Minitrons Infors ${ }^{\circledR}$.

After 24 hours, the inoculum suspension reached $2.01 \times 10^{12} \mathrm{CFU} \mathrm{ml}^{-1}$ (Colony Forming Unit) of total mesophile and $1.32 \times 10^{12} \mathrm{CFU} \mathrm{ml}^{-1}$ of total bacteria. Then, the inoculum was used to contaminate the wort. The final concentration in the wort was $1 \times 10^{7} \mathrm{CFU} \mathrm{ml}^{-1}$ of total mesophile.

\section{Treatments}

The wort utilized in the investigation was submitted to six treatments. The first treatment, the negative control - without elimination of contaminants microorganisms (T0), four treatments using different ionization radiation doses from electron beam source: 10 kGy (T1), 20kGy (T2), 40 kGy (T3), 80kGy (T4) and one treatment using steam sterilisation - as the positive control (T5), which will be detailed below.

\section{E-beam treatments}

The irradiation treatments were performed in the Technological Radiation Center (CTR) of Energy and Nuclear Research Institute (IPEN - CNEN/SP). The samples were irradiated by the Electron Beam Accelerator JOB 188 (Dynamitron ${ }^{\circledR}$ ).

The batch irradiation process was chosen, and the wort was added to borosilicate rectangular glass vessels (Pyrex ${ }^{\circledR}$ ) and packed with plastic film 0.1 $\mathrm{mm}$. Each vessel received $300 \mathrm{ml}$ of wort obtained from clarified molasses, which corresponds to a height of $4 \mathrm{~mm}$ of the sample. For each batch, 4 vessels were irradiated.

The Electron Accelerator was set to energy, width, and current of the electron beam of $2.4 \times 10^{-13} \mathrm{~J}(1.5 \mathrm{MeV}), 0.112 \mathrm{~m}$, and $5.61 \times 10^{-3} \mathrm{~A}$, respectively. The tray speed was $0.112 \mathrm{~m} \mathrm{~s}^{-1}$, proportional to a dose of $5 \mathrm{kGy}$ per run. 
The T5 treatment was performed by autoclaving the clarified molasses at $121^{\circ} \mathrm{C}, 1 \mathrm{ATM}$, for 20 minutes in a vertical autoclave $\left(\mathrm{Phoenix}{ }^{\circledR}\right.$ ).

\section{Evaluation of the contamination control}

The evaluation of the growth of total bacteria and total mesophiles was performed by the logarithmic variation in the number of $\mathrm{CFU}$ : Log (CFU $\left.\mathrm{ml}^{-1}+1\right)$. It was added 1 to the CFU because of the treatments that presented 0 CFU due to the result of Log 0 is an undefined value.

The $\mathrm{D}_{10}$ (Required dose to destroy $90 \%$ of the population or $1 \mathrm{log}$ ) for total bacteria and total mesophile were calculated in $\mathrm{kGy}$ according to Equation 1 , where $\mathrm{N}_{0}$ is the initial CFU ml$l^{-1}$ and $\mathrm{N}_{\text {final }}$ is the CFU ml${ }^{-1}$ after irradiation.

$$
D_{10}=\frac{\text { applyed dose }}{\left(\log _{10} N_{0}-\log _{10} N_{\text {final }}\right)}
$$

\section{Eq. 1}

The efficiency control of the microorganisms was calculated according to Equation 2.

$$
\text { Efficiency of control }(\%)=\left(\frac{N_{0}-N_{\text {final }}}{N_{0}}\right) \times 100
$$

Eq. 2

\section{Chemical and microbiological analyses}

After the treatments, the materials underwent chemical and microbiological analyses described below.

\section{Total mesophile and total bacteria}

For the enumeration of the microbial contamination levels, the total mesophile and total bacteria were measured by taken aseptically a sample of $1 \mathrm{ml}$ of the wort and serial diluted with $9 \mathrm{ml}$ of saline solution $(0.85 \% \mathrm{NaCl}$ in distilled water).

After the serial dilution, the samples were pour plated in Plate Count Agar (PCA) in order to determine the total mesophile and, in PCA with 10 mg $\mathrm{I}^{-1}$ to determine the total bacteria. All plating was performed in triplicate with incubation at $30{ }^{\circ} \mathrm{C}$ for 48 hours.

\section{Sugars, glycerol and mannitol}

Glycerol, mannitol and the sugars sucrose, glucose and fructose were measured by ion chromatography, following the method described by the manufacturer (Eith et al. 2006).

It was used the ion chromatograph 930 Compact IC Metrohm ${ }^{\circledR}$ equipped with the column 1 Metrosep Carb 150 / 4.0 , at $35^{\circ} \mathrm{C}$ with eluent solution of 200 $\mathrm{mM}$ sodium hydroxide and the flow was set to $0.5 \mathrm{ml} \mathrm{min}^{-1}$. The wort samples were diluted 200 times and the wine samples were diluted 50 times with ultrapure water. After that, the samples were filtered with $0.45 \mu \mathrm{m}$ cellulose acetate filter. All the samples were measured in triplicates and the volume of sample injected was $20 \mu \mathrm{L}$.

\section{Furfural and 5-hidroximetylfurfural}

Furfural and 5-hidroximetylfurfural (5-HMF) were measured by gas chromatography with Flame lonization Detector (FID), following the method 72 described by U S Department of Labor Occupational Administration Safety and Health (1988).

It was used the gas chromatograph GC-FID Shimadzu equipped with the column ZB-5 Phenomenex ${ }^{\circledR} 60 \mathrm{~m} \times 0.32 \mathrm{~mm} \times 1.00 \mu \mathrm{m}$. The chromatographic conditions were injector temperature $170^{\circ} \mathrm{C}$, injection mode split, carrier gas $\mathrm{N}_{2}$, flow rate $6.0 \mathrm{ml} \mathrm{min}^{-1}$ (carrier gas), split ratio 8.0 , column temperature 50 ${ }^{\circ} \mathrm{C}$ for $5 \mathrm{~min}$, then temperature program to $150{ }^{\circ} \mathrm{C}$ at $5^{\circ} \mathrm{C} \mathrm{min}{ }^{-1}$, detector temperature $200{ }^{\circ} \mathrm{C}$.

The wort samples were filtered with $0.45 \mu \mathrm{m}$ cellulose acetate filter and the injection volume of the sample was $2.0 \mu \mathrm{L}$.

\section{Total phenolics}

The total phenolics of the wort samples were determined according to the Folin-Ciocalteu method according to Julkunentiitto (1985) with modifications. The procedure consisted of adding $1000 \mu \mathrm{L}$ of the ample (or standard for calibration curve) and $500 \mu \mathrm{L}$ of Folin Ciocalteu reagent (10\% v/v) to a test tube, wait 40 minutes and then add $2500 \mu \mathrm{L}$ of $\mathrm{Na}_{2} \mathrm{CO}_{3}(20 \% \mathrm{~m} / \mathrm{v})$. After that, the absorbance was measured at $725 \mathrm{~nm}$ in a quartz cuvette on the spectrophotometer (UV mini-1240 Shimadzu ${ }^{\circledR}$ ). 
The standard curve was prepared with 6 points of tannic acid $\left(0,4,8,12,16,20,25 \mu \mathrm{g} \mathrm{ml}^{-1}\right)$ with 3 repetitions at each point. The samples were diluted with ultrapure water 25 times and also measured in triplicate.

\section{Total flavonoids}

The total flavonoids of the worst samples were measured according to Mabry et al. (2012) with modifications. Thus, $4.3 \mathrm{ml}$ of ethanol (70\% $\left.\mathrm{v} \mathrm{v}^{-1}\right), 100$ $\mu \mathrm{L}$ of $2 \% \mathrm{AlCl}_{3}\left(\mathrm{w} \mathrm{v}^{-1}\right.$, solution in methanol), $100 \mu \mathrm{L}$ of sodium acetate $1 \mathrm{M}$ and $500 \mu \mathrm{L}$ of the sample (or standard for calibration curve) were added to a test tube and kept at rest for 40 minutes. Then, the absorbance was measured at $415 \mathrm{~nm}$ in a quartz cuvette on a spectrophotometer (UV mini- 1240 Shimadzu ${ }^{\circledR}$.

The standard curve was prepared with 8 points of rutin solution $\left(0,1,2,4,8,16 \mu \mathrm{g} \mathrm{ml}^{-1}\right)$ with 3 repetitions each point. The samples were diluted with ethanol (70\% v/v) 50 times and also measured in triplicate.

\section{Fermentation}

The worts from all treatments, except T4 (80 kGy), were submitted to the fermentation process. e chose the treatments with the first three doses for the fermentation because we understood that these would meet the necessary conditions to reduce microbial contamination and achieve high productivity and fermentative yield glimpsing the industrial application.

The fermentation process was conducted in $500 \mathrm{ml}$ Erlenmeyer flasks containing $200 \mathrm{ml}$ of wort, with $16.7^{\circ}$ Brix, $150 \mathrm{~g} \mathrm{~L}^{-1}$ of total reducing sugars, and $3 \%$ of the dry yeast Saccharomyces cerevisiae "Fleischmann” (AB Brasil Indústria e Comércio de Alimentos Ltda).

The fermentation process was conducted with 5 replicates (reactors) per treatment, at $30{ }^{\circ} \mathrm{C}$, under 100 RPM stirring (Minitron Shaker - Infors $\mathrm{HT}^{\circledR}$ ). The process was monitored through the losses of $\mathrm{CO}_{2}$ from the reactors during the fermentation. At the end of the fermentation, yeast cell viability and total bacteria were measured, and the fermented wort was centrifuged at $3738.8 \mathrm{~g}$ (Thermo Fischer Scientific Sorval ST $40 \mathrm{R}^{\circledR}$ centrifuge), at $10{ }^{\circ} \mathrm{C}$ for 10 minutes. Then, the wine was immediately frozen $\left(-20^{\circ} \mathrm{C}\right)$ for further analyses.

The chemical and microbiological analyses of the wines were: total bacteria, sugars, glycerol and mannitol, as previously described and also yeast cell viability, yeast cell biomass and alcohol content, as described below.

\section{Yeast cell viability}

The yeast cell viability was determined according to Pierce (1970) by the differential staining of living and dead cells using $0.1 \%$ methylene blue solution and observation on an optical microscope $\left(\mathrm{Nikon}^{\circledR}\right)$. This analysis was performed at the beginning and the end of the fermentation.

The samples were prepared with the dilution of $500 \mu \mathrm{l}$ of the wine 10 times with distilled water. After that, $300 \mu \mathrm{l}$ of the suspension was transferred to a tube with $300 \mu \mathrm{l}$ of $0.1 \%$ methylene blue solution and homogenized. Then, $10 \mu \mathrm{l}$ of the suspension was transferred to a Neubauer chamber followed by the observation on a microscope (400x).

\section{Yeast cell biomass}

The yeast cell biomass was determined by the wet weight according to Zago et al. (1996). For this, the fermented wort was centrifuged at $3738.8 \mathrm{~g}$ (Thermo Fischer Scientific Sorval ST $40 \mathrm{R}^{\circledR}$ centrifuge), at $10{ }^{\circ} \mathrm{C}$ for 10 minutes. Then, the pellet mass was measured on a semi-analytical scale (BL320H Shimadzu ${ }^{\circledR}$ ) and compared with the initial mass of the sample.

\section{Alcohol content}

The alcohol content of the wine was measured by the distillation of $25 \mathrm{ml}$ of sample in a micro-distiller (MA $012 / 1 \mathrm{Marconi}^{\circledR}$ ) followed by density measurement using a Digital Densimeter (EDM 4000 Schmidt Haensch $^{\circledR}$ ) at $20 \pm 0.05^{\circ} \mathrm{C}$, according to Zago et al. (1996).

The density value of the solution was used to calculate the alcohol concentration of the sample by converting the read density in $\% \mathrm{~m} \mathrm{~m}^{-1}$ using a conversion table at $20^{\circ} \mathrm{C} / 20^{\circ} \mathrm{C}$.

\section{Fermentation yield and productivity}

The yield (practical) was calculated based on the volume of ethanol obtained from $100 \mathrm{~g}$ of sugars supplied in the substrate according to Equation 3.

Yield $=\left(\frac{\text { ml of final ethanol }}{\text { gof sugars supplied }}\right) \times 100$

Eq. 3

The productivity was calculated according to Equation 4 based on the alcohol content at the end of the fermentation t and the fermentation time. The productivity was expressed in grams of ethanol per hour $\left(\mathrm{g} \mathrm{l}^{-1} \mathrm{~h}^{-1}\right)$ 
Productivy $=\frac{\text { ethanol concentration in the wine } \mathrm{g}^{-1}}{\text { fermentation time }(h)}$

Eq. 4

\section{Electrical consumption estimation}

For the estimation of the energy cost to operate the electron accelerator used in this study, initially, it was calculated the energy consumption in KWh of the electron beam operating with a voltage of $1.5 \times 10^{6} \mathrm{~V}$ and electric current of $5.61 \times 10^{-3} \mathrm{~A}$ for 1 hour. This is the power required to irradiate a sample with a dose of $5 \mathrm{kGy}$ approximately. The total energy consumed by the accelerator peripherals such as cooling system, vacuum system, and compressed air was determined through the nominal values of the power supplied by the equipment manufacturers.

Regarding the cost of energy (US \$ / MWh), since the sucroenergetic industry is also an electricity producer, which besides being self-sufficient, is still an exporter of the surplus energy produced, it was considered that the energy consumption needed for the accelerator would no longer be commercialized. Therefore, the value of MWh was equivalent to the average amount that would be paid to the ethanol-producing industry, according to the electric energy commercialization contracts of the Brazilian Electricity Regulatory Agency (ANEEL). For this calculation, it was considered that the amount paid for 1 MWh of the excess energy produced by burning biomass (sugarcane bagasse and wood chips) by ethanol-producing plants in Brazil through public auctions held by ANEEL for energy distributors (CCEE 2021).

According to the auctions held in March / 2016 and April / 2017 (energy supplied respectively in 2020 and 2021), the average amount paid for each MWh of energy was US\$ 42.50 or US $\$ 0.0425$ / kWh (ANEEL 2021). The dollar rate (US $\$ 1.00=\mathrm{R} \$ 5.53$ ) was consulted on $3 / 21 / 2021$ on the website of the Central Bank of Brazil (BCB 2021).

\section{Experimental design and statistical analyses}

The experimental design was entirely randomized with six treatments and five replicates per treatment.

The results were submitted to analysis of variance (ANOVA) by the $\mathrm{F}$ test and the averages compared in the Tukey test at the significance level of $5 \%$ $(p \leq 0.05)$. The statistical analyses were performed using SISVAR 5.6 software (Ferreira 2014).

\section{Results And Discussion}

To meet the greenhouse gases emission reduction targets the demand for renewable biofuels has increased. For this, efforts must be made to increase industrial productivity, and for that, better control of microbiological contamination is highly necessary.

The yeast cells reuse during the season countless times can influence the contamination level of the must by bacteria and wild yeasts (Lopes et al. 2016, Brexó and Sant'Ana 2017). The development and predominance of wild strains of yeasts is undesirable for the process due to the lower productivity, flocculation, foaming, and biofilm formation produced by these microorganisms (Beckner et al. 2011, Della-Bianca and Gombert 2013, Della-Bianca et al. 2013). These drawbacks increase the use of antifoam, acids and antibiotics in the industry plant (Brexó and Sant'Ana 2017).

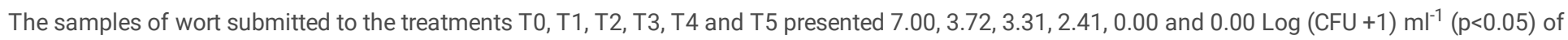
total mesophiles, respectively (Fig. 1). These results correspond to an efficiency control of the microorganism of $99.94 \%, 99.97 \%,>99.99 \%,>99.99 \%$, $100 \%$ and $100 \%(p<0.05)$ for T1, T2, T3, T4 and T5, respectively.

For total bacteria, T0, T1, T2, T3, T4 and T5 presented 5.00, 2.33, 3.22, 2.33, 0.00 and 0.00 Log (CFU +1) $\mathrm{ml}^{-1}$, respectively. These results correspond to an efficiency of control of $99.99 \%, 99.98 \%,>99.99 \%, 100 \%$ and $100 \%$ for T1, T2, T3, T4 and T5, respectively.

Therefore, the microbial contamination of the worst decreased as the irradiation dose increased, in accordance with Sampa et al. (2007) study.

Only treatments T4 (80 kGy) and T5 (steam - positive control) were able to sterilise the must. However, T3 (40 kGy) was sufficient for 4.59 -log reduction of total mesophiles and 2.67-log reduction of total bacteria, corresponding to inactivation of more than $99.99 \%$ of the microorganisms present in the must.

In a study carried out by Nobre et al. (2007) when submitting sugarcane juice to treatment with ionizing radiation ( $\mathrm{g}$ - Co ${ }^{60}$ ), the dose of $15 \mathrm{kGy}$ was not enough to fully inactivate the Bacillus subtillis culture, but achieved a reduction of more than $99.9 \%$ for these bacteria. In the present study, inactivation of total bacteria higher than $99.9 \%$ was achieved in the dose of $10 \mathrm{kGy}$. Similar results were observed for total mesophiles (Fig. 1). Furthermore, the study conducted by Nobre et al (2007) used pure cultures of bacteria while the present study used the total microbiota from a sugarcane field.

Most of the literature about microbial radioresistance is based on reports of experiments typically involving pure cultures grown under near-optimal conditions (Shuryak 2019). In this study, we used the microbiota from the soil of a sugarcane field since it is known that present many microorganisms groups in different levels. Also, other authors have reported that bacterial contamination in alcoholic fermentation is mostly from the sugarcane field soil (Gallo 1989, Figueiredo et al. 2008, Costa et al. 2015). 
A study carried out by Costa et al. (2015) assessing microbial diversity at different stages of sugarcane ethanol production identified 22 archaeal groups, 203 fungi groups and 355 bacterial groups. The authors also mentioned that the microbial contamination increases through the processes in the ethanol plant and are mostly from the feedstock and soil impurities.

Many microorganisms in soil are organic matter decomposers and also opportunistic plant/animals pathogens (Diezmann and Dietrich 2009, Sykes et al. 2014). This way of living requires being able to tolerate and possibly exploit the oxidizing compounds used as a defence mechanism by their hosts (Heller and Tudzynski 2011) this may justify the high radiotolerance of some soil microorganisms.

Also, some microorganisms can synthesize antioxidant compounds and pigments that aid in radioprotection (Kim et al. 2007), such as vitamin C (Mao et al. 2006), carotenoids (Parvathy 1983, Jain et al. 2015) and flavonoids (Molins 2001, Shuryak et al. 2017, Shuryak 2019). These compounds are commonly found in sugarcane juice (Abbas et al. 2014) and also present in the sugarcane molasses, the raw material used in this study (Table 1).

The $\mathrm{D}_{10}$ (The required dose to destroy $90 \%$ of the population) for total mesophiles was $3.06 \mathrm{kGy}$, whereas for total bacteria it was $4.81 \mathrm{kGy}$. Bacteria (prokaryotic) are more radioresistant than other microorganisms such as fungi and viruses, so it is justified that the total bacteria $D_{10}$ is higher than the total mesophiles. In addition, the values found are in accordance with the literature, which states that fungi and bacterial spores present $D_{10}$ values between 1 and 10 kGy (Confalonieri and Sommer 2011, Jung et al. 2017, Shuryak et al. 2017)

Other studies report radioresistant microorganisms like fungi that present chronic and acute radioresistance ( $\mathrm{D}_{10}$ from 0.1 to $6.5 \mathrm{kGy}$ ) (Shuryak et al. 2017), bacteria, such as Deinococcus radiodurans capable of withstanding high doses of radiation ( $D_{10}$ of 16 kGy) (Omelchenko et al. 2005) and ability to reconstruction the functional genome (Confalonieri and Sommer 2011), and also archaea, such as Thermococcus gammatolerans sp. nov., which was isolated after exposure of $30 \mathrm{kGy}$ (g-radiation)(Jolivet et al. 2003).

Moreover, Lactobacillus plantarum, one of the major contaminants of alcoholic fermentation (Dong et al. 2015, Dellias et al. 2018), is described as a chronic and acute radioresistant microorganism (Daly et al. 2004, Shuryak et al. 2017).

Most bacterial contaminants are found in the Lactobacillus genera (Bonatelli et al. 2017), especially lactic acid bacteria (LAB), like L. plantarum, which are responsible for reducing yeast cell viability due to the competition for nutrients and the production of toxic compounds, such as lactic and acetic acids during the fermentation (Narendranath et al. 1997, Costa et al. 2008).

In general, ethanol plants use antibiotics in order to control bacterial contamination. However, in some cases, does not prevent Lactobacilli infections recurrence, since these microorganisms can form biofilm, which is tolerant to the high concentration of the antibiotics and cleaning (Dellias et al. 2018, Saunders et al. 2019).

The large-scale use of antibiotic can induce bacterial resistance (Carvalho et al. 2020). Also, antibiotic residues such as virginiamycin can be found in distillers dried grain (DDG), from bioethanol fermentation of corn, which is utilized for animals feed (Bischoff et al. 2016). Regarding sugarcane bioethanol, there is a concern about antibiotic resistance in microorganisms that may be discharged into the environment through the fertigation using vinasse, the liquid waste obtained from the distillation of the wine (Mendonça et al. 2016). Furthermore, the presence of antibiotic in the vinasse can negatively affect its anaerobic digestion for the production of biogas through the inhibition of acetogenic bacteria and methanogenic archaea (Sanz et al. 1996) and reduce the potential to use vinasse to produce other products.

Therefore, a more efficient disinfection process is needed, such as ionizing radiation (IR). However, the use of IR may promote the formation of inhibitors by-products from sugar degradation (Molins 2001).

In our study, it was not observed formation and alteration in the concentration of the inhibitors flavonoids, furfural and 5-HMF ( $>0.05$ ) in any condition of treatment evaluated (Table 1). Such compounds are generally produced from sugar degradation, especially in thermal conditions (Molins 2001, Eggleston and Amorim 2006, Chi et al. 2019). However, it did not occur in this study, including in the steam treatment (T5).

The aldehydes like furfural and HMF may inhibit key enzymes intervening in the rate of protein synthesis of the central metabolism of the yeasts affecting negatively the growth and fermentation (Cabañas et al. 2019). Because of that, the presence of these compounds is highly unwanted in the fermentation substrate.

On the other hand, it was observed a gradual increase of phenolic compounds levels (6\%, 9.4\%, 17.8\% and 19.8\%, for T1, T2, T3 and T4, respectively) according to the radiation dose applied (Fig. 2). The steam treatment (T5) presented a significantly lower ( $<<0.05)$ concentration of phenolic compounds than 40 and $80 \mathrm{kGy}$, but it was statistically equal to treatments 10 and $20 \mathrm{kGy}$.

According to Rasmussen et al. (2014), the degradation of carbohydrates, especially D-glucose, D-xylose and L-arabinose can be related to the production of compounds such as phenolics. These compounds have been considered biocatalyst inhibitors (Chi et al. 2019), and their gradual production according to e-beam dose increase was also observed in Lima et al. (2016) study. But, in our work, the presence of phenolics did not inhibit yeast cell viability and biomass production ( $p>0.05)$ in any treatment during the fermentation (Table 3 ).

In a study conducted by (Martín et al. 2007) using sugarcane bagasse hydrolysate a concentration of $2100 \mu \mathrm{g} \mathrm{ml}^{-1}$ of phenolic compounds was responsible for the yeast (S. cerevisiae) inhibition and consequently, poor fermentability. In the same study using an adapted strain of the same yeast it

Page $7 / 15$ 
was observed higher ethanol yield on total sugar after $24 \mathrm{~h}\left(0.38 \mathrm{~g} \mathrm{~g}^{-1}\right)$ than the non-adapted yeast $\left(0.18 \mathrm{~g} \mathrm{~g}^{-1}\right)$ in wort with $1400 \mu \mathrm{g} \mathrm{ml} \mathrm{l}^{-1}$ of phenolic compounds. In our study, although the yeast has not been adapted to inhibitory toxins, the concentration of phenolics was below $1089.38 \mu \mathrm{g} \mathrm{ml}^{-1}$ ( $\mathrm{Table}$ 1 ) in all fermented treatments, which probably reflected the $S$. cerevisiae tolerance to these compounds.

In addition to the low formation of inhibitors, it was not observed significant inversion of TRS (Total Reducing Sugars) in all treatments ( $\mathrm{p}>0.05$ ) (Table 2). Otherwise, Lima et al. (2016) observed significant ( $p<0.05)$ TRS inversion in sugarcane juice irradiate with $20 \mathrm{kGy}$ e-beam dose.

The fact that in our study the reduction in the concentration of TRS was not observed is interesting because low sugar degradation is essential in a decontamination method aiming no decrease in the ethanol yield due to the sugars degradation (Alcarde et al. 2000, 2003).

Regarding sucrose, it was observed a decrease in steam treatment $(p<0.05)$. However, there was no decrease in concentration $(p>0.05)$ in the irradiated treatments (Fig. 3). In a study by Podadera (2007), using electron beam to sterilise invert sugar syrup, it was observed a significant decrease ( $<<0.05)$ in sucrose concentrations between the control, 5, 10 and $30 \mathrm{kGy}$ samples. Moreover, glucose and fructose concentrations increased significantly ( $p<0.05$ ). Which indicated the degradation of the disaccharide with the breakdown of the glycosidic bond and formation of the reducing sugars glucose and fructose.

At the end of the fermentation, sucrose was not detected in any treatment, in addition, the residual sugars glucose and fructose presented low concentrations $(<0.05 \%)$ in all treatments $(p>0.05)$, evidencing efficient consumption of sugars by yeasts or other microorganisms during the fermentation process (Table 3).

The concentration of glycerol was similar in the wine from all treatments, approximately 15 grams per liters $(p>0.05)$. Bai et al. (2008) indicate that during the fermentation commonly a level of about $1 \%\left(\mathrm{w} / \mathrm{v}, 10 \mathrm{~g} \mathrm{l}^{-1}\right)$ of glycerol is produced.

The high concentration of glycerol in wine can be an indicator of the yeast response to the adversity. High sugar values lead to high concentrations of glycerol in the must, due to the increase in osmotic pressure (Ponce et al. 2016), as well as the presence of bacterial contamination (Li et al. 2009).

There was bacterial contamination in the wine of all treatments. However, the control treatment presented a higher value ( $\mathrm{p}<0.05)$ of 5.55 log $\left(\mathrm{CFU} \mathrm{ml}^{-}\right.$ $\left.{ }^{1}+1\right)$. The presence of bacteria in all the treatments may be due to the contamination during the experiment sampling and poor asepsis.

As well as the high bacterial contamination, the control treatment (T0) presented a higher concentration of mannitol $\left(0.41 \mathrm{~g} \mathrm{I}^{-1}\right)$ when compared with other treatments $(\mathrm{p}<0.05)$. Mannitol is a sensitive indicator of contamination and its presence is an indication of the enzymatic dehydrogenation of fructose carried out exclusively by bacteria (Eggleston et al. 2007).

The T3 wine exhibit the lowest concentration of mannitol $\left(0.33 \mathrm{~g} \mathrm{l}^{-1}\right)$ when compared with the other treatments $(p<0.05)$. This was expected because among the treatments submitted to fermentation T3 presented the greatest contamination control. This result is remarkably interesting because according to Eggleston et al. (2007) high concentrations of mannitol may promote yeast flocculation and reduce the efficiency and productivity of the fermentation. The authors also described that a concentration around $6 \mathrm{~g} \mathrm{~L}^{-1}$ of mannitol can cause a decrease of $4 \%$ in ethanol yield.

The control (T0) showed the lowest yield (88\%) of the treatments. It is justified due to high bacterial contamination in wine (5.55 log) and conversion of sugars into metabolites such as glycerol and mannitol (Table 3). The highest fermentation yield was reached in the steam treatment (T5) with $95 \%$ ( $p<0.05$ ). Right below, the treatments $20 \mathrm{kGy}$ (T2) and $40 \mathrm{kGy}$ (T3) presented $93 \%$ yield ( $>>0.05)$. Higher than usually fed-batch industrial fermentations with $87 \%$ average of fermentation using molasses as raw material (Andrietta and Maugeri 1994, Viegas et al. 2002) and also greater than the yield described by Alcarde et al. (2001) which achieved $90.56 \%$ in the fermentation of sugarcane juice treated with $10 \mathrm{kGy}$ (g radiation).

There are great importance and interest in increasing the yield of industrial fermentation. A yield of $93 \%$ could be responsible for a significant increase in ethanol production and, consequently, in the revenue of the industrial plant.

Regarding ethanol productivity, it decreased with the contamination whereas the control treatment showed the lowest value of $0.85 \mathrm{~g} \mathrm{I}^{-1} \mathrm{~h}^{-1}$ (Table 3 ). The highest productivity has been achieved in steam treatment $\left(0.91 \mathrm{~g} \mathrm{l}^{-1} \mathrm{~h}^{-1}\right)$ followed by 10 and $20 \mathrm{kGy}$ treatments with $0.89 \mathrm{~g} \mathrm{I}^{-1} \mathrm{~h}^{-1}$ in both $(\mathrm{p}>0.05)$ and 40 $\mathrm{kGy}$ treatment with $0.87 \mathrm{~g} \mathrm{l}^{-1} \mathrm{~h}^{-1}(\mathrm{p}<0.05)$. Thus, the treatment of $20 \mathrm{kGy}$ showed better productivity $(\mathrm{p}<0.05)$ and the same yield as treatment $40 \mathrm{kGy}$, which requires more energy.

Due to that, the dose of $20 \mathrm{kGy}$ is the most recommended as it requires less energy consumption to allow the results with very positive response in the control of the contamination and on the fermentation process.

It is believed that greater changes in the fermentative behaviour of the irradiated wort could have been observed if consecutive fermentative recycles and acid treatment of yeast from the control treatment had been carried out. Since the microbial contamination tends to increase throughout the fermentative recycles during the harvest season, as described in the literature (Ceccato-Antonini 2018).

It is also necessary to study more the application of this technology, as well as the increase of the scale and the economic viability. 
In our work, the electrical energy consumption to operate the electron accelerator at full power in one hour of use was approximately $150 \mathrm{kWh}$. Only the electron beam is responsible for $25 \%(37.5 \mathrm{kWh})$ of this total. The cooling system, vacuum system, compressed air and other devices consumed the remaining $75 \%$ (112.5 $\mathrm{kWh})$. In this case, the cost was US\$ 6.43 per hour.

For the present case, the electron beam was not used at its maximum power. Due to this, for each hour of use of the accelerator, the electrical energy consumption was $122 \mathrm{kWh}$, of which $113.58 \mathrm{kWh}$ were consumed by the devices of each system mentioned above. Only $8.42 \mathrm{kWh}$ was consumed by the electron beam. The cost was about US\$ 5.23 per hour of operation.

Table 4 presents the operating cost, taking into account only the energy consumption of the electron accelerator for each treatment. $\Delta t$ is the processing time (or sterilisation) of the samples by e-beam. Their values were obtained considering the conveyor speed of $0.112 \mathrm{~m} \mathrm{~s}^{-1}$ and the linear length of two aligned trays equal to $0.40 \mathrm{~m}$.

Therefore, operating at a dose of $20 \mathrm{kGy}$, the energy consumption by the electron accelerator is estimated at $146.18 \mathrm{kWh}(33.68 \mathrm{kWh})$ consumed by the electron beam and the rest by the peripheral equipment. The cost of each hour of operation of the accelerator is estimated at US\$ 6.27 . Considering that in the ethanol-producing plants in Brazil an average of $450 \mathrm{~m}^{3}$ of wort is produced per hour, the estimated cost of processing $1 \mathrm{~m}^{3}$ of this material is US\$0.014.

It is important to note that the sugarcane mills can process $1 \mathrm{~m}^{3}$ of the wort in a short time. Furthermore, the e-beam technology is very fast, and, in a few seconds, the desired result in microbial control can be achieved. This allows the treatment of large volumes of wort in a short time, which facilitates this process implementation in large industries.

It should be mentioned that apart from sterilisation of the wort, to have success in the contaminating control in the ethanol industry it is necessary an adequate system to cleaning fermenters, pipeline, centrifuges, valves and other compartments used to transport or store wine, yeast cream and wort.

With that, the use of e-beam for sterilisation of the substrate could also make it possible to use more productive yeast strains in the fermentation, such as the thermotolerant strains of $S$. cerevisiae described by Pattanakittivorakul et al. (2019), which show extremely high ethanol production at $40{ }^{\circ} \mathrm{C}$, in addition to tolerating high gravity fermentation and high concentrations of furfural, HMF and acetic acid.

It should be noted that the e-beam could also be applied in other processes within the industry, as in the pretreatment of biomass for the production of second-generation ethanol (Postek et al. 2018). The biomass irradiation can facilitate enzymatic hydrolysis with lower temperatures and minimal formation of inhibitory by-products when compared to conventional pretreatments (Singh et al. 2016).

\section{Conclusion}

The dose of $80 \mathrm{kGy}$ was sufficient for sterilisation of the wort from molasses. Also, the lower dose tested of $10 \mathrm{kGy}$ were able to reduce more than $99.9 \%$ of the microbial contamination present in the substrate. The treatment of $20 \mathrm{kGy}$ showed the best yield and ethanol productivity among the irradiated worts, evidencing the possibility of applying the e-beam in the treatment of wort for fermentation, which may allow reduction in losses caused by microbial contamination, besides the possibility of promoting fermentation yield and productivity increase.

\section{Declarations}

Ethical approval No ethical approval was required, as human participants or animals were not involved in this research.

Consent to participate not applicable.

Consent to publish All authors have read and agreed to the published version of the manuscript.

Authors contributions Conceptualization: RP, EA, VA, and AS, Methodology: RP, EA, MP, AP, and LA, Formal analysis and investigation: RP, EA, and MP, Resources: VA and AS, Writing - review and editing: RP and AS, Supervision: AS and VA, Funding acquisition: AS.

Funding This study was financed in part by the Coordenação de Aperfeiçoamento de Pessoal de Nível Superior - Brasil (CAPES) - Finance Code 001 and National Council for Scientific and Technological Development (CNPq).

Competing Interests The authors declare no competing interests.

Availability of data and material not applicable

Code availability not applicable

\section{References}

1. Abbas, S. R., Sabir, S. M., Ahmad, S. D., et al. (2014). Phenolic profile, antioxidant potential and DNA damage protecting activity of sugarcane (Saccharum officinarum). Food Chem, 147, 10-16. doi:10.1016/j.foodchem.2013.09.113.

Page 9/15 
2. Alcarde, A. R., Marcos, J., \& Walder, M. (2001). Comparison Between Gamma Radiation and Kamoran HJ in the Decontamination of Kamoran H Sugarcane Must. J Food Process Preserv, 25, 137-147.

3. Alcarde, A. R., Marcos, J., \& Walder, M. (2000) J in the Decontamination of Kamoran H Sugarcane Must. 25:137-147.

4. Alcarde, A. R., Walder, J. M. M., \& Horii, J. (2003). Fermentation of irradiated sugarcane must. Sci Agric, 60, 677-681. doi:10.1590/s010390162003000400011.

5. Amorim, H. V., Lopes, M. L., de Castro Oliveira, J. V., et al. (2011). Scientific challenges of bioethanol production in Brazil. Appl Microbiol Biotechnol, 91, 1267-1275. doi:10.1007/s00253-011-3437-6.

6. Amorim, H. V., Oliveira, A. J., \& Campos, H. (1981) Infecção, problema sério na produção de álcool. In: Congresso Nacional da Sociedade dos Técnicos Açucareiros do Brasil. pp 158-168.

7. Andrietta, S. R., \& Maugeri, F. (1994) Optimum Design of a Continuous Fermentation Unit of an Industrial Plant for Alcohol Production. In: Advances in Bioprocess Engineering. Springer Netherlands, pp 47-52.

8. ANEEL (2021) Resultado de Leilões - ANEEL: Planilha em Excel. https://www.aneel.gov.br/resultados-de-leiloes. Accessed 26 Mar 2021.

9. Bai, F. W., Anderson, W. A., \& Moo-Young, M. (2008). Ethanol fermentation technologies from sugar and starch feedstocks. Biotechnol Adv, 26, 89105. doi:10.1016/j.biotechadv.2007.09.002.

10. Basso, L. C., Basso, T. O., \& Rocha, S. (2011). Ethanol Production in Brazil: The Industrial Process and Its Impact on Yeast Fermentation. In M. A. S. Bernardes (Ed.), Biofuel production-recent developments and prospects (pp. 85-100). Rijeka: InTech.

11. Basso, L. C., De Amorim, H. V., De Oliveira, A. J., \& Lopes, M. L. (2008). Yeast selection for fuel ethanol production in Brazil. FEMS Yeast Res, 8, 1155-1163. doi:10.1111/j.1567-1364.2008.00428.x.

12. BCB (2021) Cotação do dólar USA. https://www.bcb.gov.br/. Accessed 24 Mar 2021.

13. Beckner, M., Ivey, M. L., \& Phister, T. G. (2011). Microbial contamination of fuel ethanol fermentations. Lett Appl Microbiol, 53, $387-394$. doi:10.1111/j.1472-765X.2011.03124.x.

14. Bischoff, K. M., Zhang, Y., \& Rich, J. O. (2016). Fate of virginiamycin through the fuel ethanol production process. World J Microbiol Biotechnol, 32, 1-7. doi:10.1007/s11274-016-2026-3.

15. Bonatelli, M. L., Quecine, M. C., Silva, M. S., \& Labate, C. A. (2017). Characterization of the contaminant bacterial communities in sugarcane firstgeneration industrial ethanol production. FEMS Microbiol Lett, 364, 1-8. doi:10.1093/femsle/fnx159.

16. Braga, V. S. (2006) A Influência da Temperatura na Condução de Dois Processos Fermentativos para Produção de Cachaça. Universidade de São Paulo.

17. Brexó, R. P., \& Sant'Ana, A. S. (2017). Impact and significance of microbial contamination during fermentation for bioethanol production. Renewable and Sustainable Energy Reviews, 73, 423-434.

18. Brown, N. A., de Castro, P. A., de Castro Pimentel Figueiredo, B., et al. (2013). Transcriptional profiling of Brazilian Saccharomyces cerevisiae strains selected for semi-continuous fermentation of sugarcane must. FEMS Yeast Res, 13, 277-290. doi:10.1111/1567-1364.12031.

19. Cabañas, K. T., Peña-Moreno, I. C., Parente, D. C., et al. (2019). Selection of Saccharomyces cerevisiae isolates for ethanol production in the presence of inhibitors. 3 Biotech, 9, 1-11. doi:10.1007/s13205-018-1541-3.

20. Carvalho, R. S., Cruz, I. A., Américo-Pinheiro, J. H. P., et al. (2020). Interaction between Saccharomyces cerevisiae and Lactobacillus fermentum during co-culture fermentation. Biocatal Agric Biotechnol, 29, 101756. doi:10.1016/j.bcab.2020.101756.

21. CCEE (2021) Ambiente de contratação regulada. https://www.ccee.org.br/portal/faces/pages_publico/onde-atuamos/comercializacao?_adf.ctrlstate=19fhn2ghfl_1\&_afrLoop=112452198849623\#!\%40\%40\%3F_afrLoop\%3D112452198849623\%26_adf.ctrl-state\%3D19fhn2ghfl_5. Accessed 26 Mar 2021.

22. Ceccato-Antonini, S. R. (2018). Conventional and nonconventional strategies for controlling bacterial contamination in fuel ethanol fermentations. World J Microbiol Biotechnol, 34, 1-11. doi:10.1007/s11274-018-2463-2.

23. Cervi, W., Lamparelli, R. A. C., Seabra, J. E. A., et al. (2019). Bioelectricity potential from ecologically available sugarcane straw in Brazil: A spatially explicit assessment. Biomass and Bioenergy, 122, 391-399. doi:10.1016/j.biombioe.2019.02.001.

24. Chi, Z., Zhao, X., Daugaard, T., et al. (2019). Comparison of product distribution, content and fermentability of biomass in a hybrid thermochemical/biological processing platform. Biomass and Bioenergy, 120, 107-116. doi:10.1016/j.biombioe.2018.11.006.

25. Confalonieri, F., \& Sommer, S. (2011) Bacterial and archaeal resistance to ionizing radiation. J Phys Conf Ser 261. doi:10.1088/1742$6596 / 261 / 1 / 012005$.

26. Costa, M. A. S., Cerri, B. C., \& Ceccato-Antonini, S. R. (2018). Ethanol addition enhances acid treatment to eliminate Lactobacillus fermentum from the fermentation process for fuel ethanol production. Lett Appl Microbiol, 66, 77-85. doi:10.1111/lam.12819.

27. Costa, O. Y. A., Souto, B. M., Tupinambá, D. D., et al. (2015). Microbial diversity in sugarcane ethanol production in a Brazilian distillery using a culture-independent method. Journal of industrial microbiology \& biotech, 42, 73-84. doi:10.1007/s10295-014-1533-1.

28. Costa, V. M., Basso, T. O., Angeloni, L. H. P., et al. (2008). Production of acetic acid, ethanol and optical isomers of lactic acid by Lactobacillus strains isolated from industrial ethanol fermentations. Cienc e Agrotecnologia, 32, 503-509. doi:10.1590/s1413-70542008000200025. 
29. da Silva-Neto, J. M., Covre, E. A., Rosa, B. C., \& Ceccato-Antonini, S. R. (2020). Can ethanol partially or fully replace sulfuric acid in the acid wash step of bioethanol production to fight contamination by Lactobacillus fermentum? Brazilian J Chem Eng, 37, 323-332. doi:10.1007/s43153-020-00033$\mathrm{x}$.

30. Daly, M. J., Gaidamakova, E. K., Matrosova, V. Y., et al. (2004). Accumulation of Mn(II) in Deinicoccus radiodurans facilitates gamma-radiation resistance. Science, 306, 1025-1028. doi:10.1126/science.1103185.

31. Della-Bianca, B. E., Basso, T. O., Stambuk, B. U., et al. (2013). What do we know about the yeast strains from the Brazilian fuel ethanol industry? Appl. Microbiol. Biotechnol., 97, 979-991.

32. Della-Bianca, B. E., \& Gombert, A. K. (2013). Stress tolerance and growth physiology of yeast strains from the Brazilian fuel ethanol industry. Antonie van Leeuwenhoek. Int J Gen Mol Microbiol, 104, 1083-1095. doi:10.1007/s10482-013-0030-2.

33. Dellias, M., de TF, Borges, C. D., Lopes, M. L., et al. (2018). Biofilm formation and antimicrobial sensitivity of lactobacilli contaminants from sugarcane-based fuel ethanol fermentation. Antonie van Leeuwenhoek. Int J Gen Mol Microbiol, 111, 1631-1644. doi:10.1007/s10482-018-1050-8.

34. Diezmann, S., \& Dietrich, F. S. (2009) Saccharomyces cerevisiae: Population divergence and resistance to oxidative stress in clinical, domesticated and wild isolates. PLoS One 4:. doi:10.1371/journal.pone.0005317.

35. Dong, S. J., Lin, X. H., \& Li, H. (2015). Regulation of Lactobacillus plantarum contamination on the carbohydrate and energy related metabolisms of Saccharomyces cerevisiae during bioethanol fermentation. Int J Biochem Cell Biol, 68, 33-41. doi:10.1016/j.biocel.2015.08.010.

36. Eggleston, G., \& Amorim, H. (2006). Reason for the chemical destruction of sugars during the processing of sugarcane for raw sugar and fuel alcohol production. Int Sugar J, 108, 271-282.

37. Eggleston, G., Basso, L. C., de Amorim, H. V., et al. (2007). Mannitol as a sensitive indicator of sugarcane deterioration and bacterial contamination in fuel alcohol production. Zuckerindustrie Sugar Ind, 132, 33-39.

38. Eith, C., Kolb, M., Seubert, A., \& Viehweger, K. H. (2006). Practical Ion Chromatography: An Introduction. Switzerland: Metrohm, Herisau.

39. Ferreira, D. F. (2014). Sisvar: a guide for its bootstrap procedures in multiple comparisons. Cienc e Agrotecnologia, 38, $109-112$. doi:10.1590/S1413-70542014000200001.

40. Figueiredo, I. C., Maciel, B. F., \& Marques, M. O. (2008) A qualidade da cana-de-açúcar como matéria-prima para produção de álcool. Nucleus special:82-92. doi:10.3738/1982.2278.93.

41. Gallo, C. R. (1989) Determinação da microbiota bacteriana de mosto e de dornas na fermentação alcoolica. University of Campinas.

42. Heller, J., \& Tudzynski, P. (2011). Reactive Oxygen Species in Phytopathogenic Fungi: Signaling, Development, and Disease. Annu Rev Phytopathol, 49, 369-390. doi:10.1146/annurev-phyto-072910-095355.

43. Jain, R., Verma, R., Singh, A., et al. (2015). Influence of selenium on metallothionein gene expression and physiological characteristics of sugarcane plants. Plant Growth Regul, 77, 109-115. doi:10.1007/s10725-015-0042-1.

44. Jolivet, E., L'Haridon, S., Corre, E., et al. (2003). Thermococcus gammatolerans sp. nov., a hyperthermophilic archeon from a deep-sea hydrothermal vent that resists ionizing radiation. Int J Syst Evol Microbiol, 53, 847-851. doi:10.1099/ijs.0.02503-0.

45. Julkunentiitto, R. (1985). Phenolic constituents in the leaves of northern willows - Methods for the analysis of certain phenolics. J Agric Food Chem, 33, 213-217. doi:10.1021/jf00062a013.

46. Jung, K. W., Lim, S., \& Bahn, Y. S. (2017). Microbial radiation-resistance mechanisms. J Microbiol, 55, 499-507. doi:10.1007/s12275-017-7242-5.

47. Kim, D., Song, H., Lim, S., et al. (2007). Effects of gamma irradiation on the radiation-resistant bacteria and polyphenol oxidase activity in fresh kale juice. Radiat Phys Chem, 76, 1213-1217. doi:10.1016/j.radphyschem.2006.12.003.

48. Kochetkov, N. K., Kudrjashov, L. I., \& Chlenov, M. A. (1979). Radiation chemistry of carbohydrates (1st ed.). Oxford: Pergamon Press.

49. Kurilova, A. A., Poloskov, A. V., Chubik, M. V., \& Ponomarev, D. V. (2015). Application of Electron Beam for Wastewater Disinfection. Procedia Chem, 15, 187-192. doi:10.1016/j.proche.2015.10.030.

50. Li, L. L., Ye, Y. R., Pan, L., et al. (2009). The induction of trehalose and glycerol in Saccharomyces cerevisiae in response to various stresses. Biochem Biophys Res Commun, 387, 778-783. doi:10.1016/j.bbrc.2009.07.113.

51. Lima, R. B., de Aguiar, C. L., Galaverna, R., et al. (2016). Sucrose and color profiles in sugarcane (Saccharum sp.) juice analyzed by UFLC-ELSD and Synapt High-Definition Mass Spectrometry during radiation treatment. Radiat Phys Chem, 121, 99-105. doi:10.1016/j.radphyschem.2015.12.022.

52. Lopes, M. L., Paulillo, S. C., de L., Godoy A, et al (2016). Ethanol production in Brazil: a bridge between science and industry. Brazilian J Microbiol, 47, 64-76. doi:10.1016/j.bjm.2016.10.003.

53. Lung, H. M., Cheng, Y. C., Chang, Y. H., et al. (2015). Microbial decontamination of food by electron beam irradiation. Trends Food Sci Technol, 44, 66-78. doi:10.1016/j.tifs.2015.03.005.

54. Mabry, T. J., Markham, K. R., \& Thomas, M. B. (2012) The systematic identification of flavonoids. Springer Science \& Business Media.

55. Mao, L., Que, F., \& Wang, G. (2006). Sugar metabolism and involvement of enzymes in sugarcane (Saccharum officinarum L.) stems during storage. Food Chem, 98, 338-342. doi:10.1016/j.foodchem.2005.05.076.

56. Martín, C., Marcet, M., Almazán, O., \& Jönsson, L. J. (2007). Adaptation of a recombinant xylose-utilizing Saccharomyces cerevisiae strain to a sugarcane bagasse hydrolysate with high content of fermentation inhibitors. Bioresour Technol, 98, 1767-1773.

doi:10.1016/j.biortech.2006.07.021.

Page $11 / 15$ 
57. Mendonça, A. A., de Lucena, B. T. L., de Morais, M. M. C., \& de Morais, M. A. (2016). First identification of Tn916-like element in industrial strains of Lactobacillus vini that spread the tet-M resistance gene. FEMS Microbiol Lett, 363, fnv240. doi:10.1093/femsle/fnv240.

58. Molins, R. A. (2001) Food Irradiation: Principles and Applications. John Wiley \& Sons.

59. Muthaiyan, A., Limayem, A., \& Ricke, S. C. (2011). Antimicrobial strategies for limiting bacterial contaminants in fuel bioethanol fermentations. Prog Energy Combust Sci, 37, 351-370. doi:10.1016/j.pecs.2010.06.005.

60. Narendranath, N. V., Hynes, S. H., Thomas, K. C., \& Ingledew, W. M. (1997) Effects of lactobacilli on yeast-catalyzed ethanol fermentations. Appl Environ Microbiol 63.

61. Nie, J. H., Chen, Z. H., Liu, X., et al. (2012). Oxidative damage in various tissues of rats exposed to radon. J Toxicol Environ Heal - Part A Curr Issues, 75, 694-699. doi:10.1080/15287394.2012.690086.

62. Nobre, P., Horii, J., \& Alcarde, R. (2007). Associação Com Bactérias Contaminantes Da Fermentação Alcoólica With Contaminant Bacteria of Alcoholic Fermentation. Ciênc Tecnol Aliment, 27, 20-25.

63. Nolasco, J. Jr. (2010). Eficiência de processo térmico para mostos a base de caldo de cana e melaço na produção de bioetanol. Campinas: Universidade Estadual de Campinas.

64. Omelchenko, M. V., Wolf, Y. I., Gaidamakova, E. K., et al. (2005). Comparative genomics of Thermus thermophilus and Deinococcus radiodurans: Divergent routes of adaptation to thermophily and radiation resistance. BMC Evol Biol, 5, 1-22. doi:10.1186/1471-2148-5-57.

65. Parvathy, K. (1983) Bottling of sugarcane juice. In: Proceedings of the scheme for studies on postharvest technology (ICAR). pp 13-16.

66. Pattanakittivorakul, S., Lertwattanasakul, N., Yamada, M., \& Limtong, S. (2019). Selection of thermotolerant Saccharomyces cerevisiae for high temperature ethanol production from molasses and increasing ethanol production by strain improvement. Antonie van Leeuwenhoek. Int $J$ Gen Mol Microbiol, 112, 975-990. doi:10.1007/s10482-019-01230-6.

67. Pierce, J. S. (1970). Institute of Brewing: Analysis committee measurement of yeast viability. Journal Inst Brew, 76, $442-443$.

68. Podadera, P. (2007) Estudo das propriedades do açúcar líquido invertido processado com radiação gama e feixe de elétrons. University of São Paulo.

69. Ponce, G. H. S. F., Moreira Neto, J., De Jesus, S. S., et al. (2016). Sugarcane molasses fermentation with in situ gas stripping using low and moderate sugar concentrations for ethanol production: Experimental data and modeling. Biochem Eng J, 110, $152-161$. doi:10.1016/j.bej.2016.02.007.

70. Postek, M. T., Poster, D. L., Vládar, A. E., et al. (2018). lonizing radiation processing and its potential in advancing biorefining and nanocellulose composite materials manufacturing. Radiat Phys Chem, 143, 47-52. doi:10.1016/j.radphyschem.2017.09.015.

71. Rasmussen, H., Sørensen, H. R., \& Meyer, A. S. (2014). Formation of degradation compounds from lignocellulosic biomass in the biorefinery: Sugar reaction mechanisms. Carbohydr Res, 385, 45-57. doi:10.1016/j.carres.2013.08.029.

72. Sampa, M. H. O., Takács, E., Gehringer, P., et al. (2007). Remediation of polluted waters and wastewater by radiation processing. Nukleonika, 52, 137-144.

73. Sanz, J. L., Rodríguez, N., \& Amils, R. (1996). The action of antibiotics on the anaerobic digestion process. Appl Microbiol Biotechnol, 46, $587-592$. doi:10.1007/s002530050865.

74. Saunders, L. P., Bischoff, K. M., Bowman, M. J., \& Leathers, T. D. (2019). Inhibition of Lactobacillus biofilm growth in fuel ethanol fermentations by Bacillus. Bioresour Technol, 272, 156-161. doi:10.1016/j.biortech.2018.10.016.

75. Schwarz, H. A. (1981). Free radicals generated by radiolysis of aqueous solutions. J Chem Educ, 58, 101. doi:10.1021/ed058p101.

76. Shuryak, I. (2019). Review of microbial resistance to chronic ionizing radiation exposure under environmental conditions. Journal of Environmental Radioactivity, 196, 50-63.

77. Shuryak, I., Matrosova, V. Y., Gaidamakova, E. K., et al. (2017). Microbial cells can cooperate to resist high-level chronic ionizing radiation. PLoS One, 12, 1-24. doi:10.1371/journal.pone.0189261.

78. Silindir, M., \& Özer, A. Y. (2009). Sterilization methods and the comparison of E-beam sterilization with gamma radiation sterilization. Fabad J Pharm Sci, 34, 43-53.

79. Singh, R., Krishna, B. B., Kumar, J., \& Bhaskar, T. (2016). Opportunities for utilization of non-conventional energy sources for biomass pretreatment. Bioresour Technol, 199, 398-407. doi:10.1016/j.biortech.2015.08.117.

80. Stockwell, B. R., Angeli, J. P. F., Bayir, H., et al. (2017). Ferroptosis: A Regulated Cell Death Nexus Linking Metabolism, Redox Biology, and Disease. Cell, 171, 273-285.

81. Sykes SM, Szaniszlo PJ, Wang Z, et al (2014) Comparative Genomic and Transcriptomic Analysis of Wangiella dermatitidis, A Major Cause of Phaeohyphomycosis and a Model Black Yeast Human Pathogen. G3: Genes|Genomes|Genetics 4:561-578. doi: 10.1534/g3.113.009241.

82. U S Department of Labor Occupational Administration Safety and Health. (1988). Method 72. In Organic Methods Evaluation Branch. Salt Lake City: OSHA Analytical Laboratory.

83. Viegas, M. C., Andrietta, S. R., \& Andrietta, M. G. S. (2002). Use of tower reactors for continuous ethanol production. Brazilian J Chem Eng, 19, 167173. doi:10.1590/S0104-66322002000200012.

84. Zago, E., Silva, L., Bernardino, C. D., \& Amorim, H. V. (1996) Métodos analíticos para o controle da produção de álcool e açúcar. 194. 


\section{Tables}

Table 1. Chemical determinations of inhibitory by-products in the sugarcane molasses wort after treatments

\begin{tabular}{|lllll|}
\hline Treatment & Flavonoids & Phenolics & Furfural & 5-HMF \\
\hline T0 - Control & $26.74 \pm 1.57^{\mathrm{a}}$ & $925.27 \pm 13.72^{\mathrm{c}}$ & $0.61 \pm 0.00^{\mathrm{a}}$ & $0.44 \pm 0.00 \mathrm{a}$ \\
\hline T1 - $10 \mathrm{kGy}$ & $23.47 \pm 5.22^{\mathrm{a}}$ & $980.68 \pm 11.74^{\mathrm{b}}$ & $0.64 \pm 0.02^{\mathrm{a}}$ & $0.44 \pm 0.02^{\mathrm{a}}$ \\
\hline T2 - $20 \mathrm{kGy}$ & $25.18 \pm 7.92^{\mathrm{a}}$ & $1012.64 \pm 16.20^{\mathrm{b}}$ & $0.62 \pm 0.02^{\mathrm{a}}$ & $0.44 \pm 0.02^{\mathrm{a}}$ \\
T3 - $40 \mathrm{kGy}$ & $25.44 \pm 1.11^{\mathrm{a}}$ & $1089.38 \pm 9.94^{\mathrm{a}}$ & $0.62 \pm 0.01^{\mathrm{a}}$ & $0.43 \pm 0.01^{\mathrm{a}}$ \\
\hline T4 - $80 \mathrm{kGy}$ & $27.99 \pm 4.61^{\mathrm{a}}$ & $1108.79 \pm 28.00^{\mathrm{a}}$ & $0.63 \pm 0.01^{\mathrm{a}}$ & $0.45 \pm 0.01^{\mathrm{a}}$ \\
\hline T5 - Steam & $32.55 \pm 4.75^{\mathrm{a}}$ & $993.77 \pm 27.33^{\mathrm{b}}$ & $0.64 \pm 0.01^{\mathrm{a}}$ & $0.42 \pm 0.01^{\mathrm{a}}$ \\
\hline C.V. & 18.6 & 1.68 & 2.22 & 3.54 \\
\hline
\end{tabular}

Averages of $n=5 \pm$ standard deviation. Superscript equal letters in the same column do not differ statistically by the Tukey test at the $5 \%$ level of significance.

Table 2. Behaviour of sugars, glycerol and mannitol in sugarcane molasses wort after treatments

\begin{tabular}{|lllllll|}
\hline & Sucrose & Fructose & Glucose & Glycerol & Mannitol & TRS \\
\hline Treatment & $\mathrm{g} \mathrm{l}^{-1}$ & & & & & \\
\hline Control & $102.03 \pm 0.09^{\mathrm{a}}$ & $22.47 \pm 0.31^{\mathrm{b}}$ & $22.55 \pm 0.14^{\mathrm{b}}$ & $<\mathrm{LOQ}$ & $0.28 \pm 0,01^{\mathrm{ab}}$ & $152.15 \pm 0.52^{\mathrm{a}}$ \\
\hline $10 \mathrm{kGy}$ & $102.77 \pm 0.47^{\mathrm{a}}$ & $21.04 \pm 0.89^{\mathrm{bc}}$ & $22.24 \pm 1.43^{\mathrm{b}}$ & $<\mathrm{LOQ}$ & $0.28 \pm 0,01^{\mathrm{ab}}$ & $151.19 \pm 2.44^{\mathrm{a}}$ \\
\hline $20 \mathrm{kGy}$ & $103.30 \pm 3.79^{\mathrm{a}}$ & $20.04 \pm 1.00^{\mathrm{c}}$ & $20.88 \pm 1.55^{\mathrm{b}}$ & $<\mathrm{LOQ}$ & $0.30 \pm 0,06^{\mathrm{a}}$ & $149.38 \pm 4.33^{\mathrm{a}}$ \\
\hline $40 \mathrm{kGy}$ & $99.65 \pm 0.09^{\mathrm{a}}$ & $20.35 \pm 0.54^{\mathrm{c}}$ & $21.00 \pm 0.65^{\mathrm{b}}$ & $<\mathrm{LOQ}^{\mathrm{a}}$ & $0.27 \pm 0,01^{\mathrm{ab}}$ & $145.99 \pm 1.19^{\mathrm{a}}$ \\
\hline $80 \mathrm{kGy}$ & $101.49 \pm 2.30^{\mathrm{a}}$ & $20.10 \pm 0.11^{\mathrm{c}}$ & $21.05 \pm 0.13^{\mathrm{b}}$ & $<\mathrm{LOQ}^{\mathrm{a}}$ & $0.22 \pm 0,02^{\mathrm{b}}$ & $147.72 \pm 2.65^{\mathrm{a}}$ \\
\hline Steam & $94.19 \pm 0.27^{\mathrm{b}}$ & $26.05 \pm 0.10^{\mathrm{a}}$ & $25.08 \pm 0.02^{\mathrm{a}}$ & $<\mathrm{LOQ}$ & $0.27 \pm 0,00^{\mathrm{ab}}$ & $150.02 \pm 0.40^{\mathrm{a}}$ \\
\hline CV & 1.82 & 2.8 & 4.09 & 0 & 9.02 & 1.58 \\
\hline
\end{tabular}

$<$ LoQ: lower than Limit of Quantification. Averages of $n=5 \pm$ standard deviation. Superscript equal letters in the same column do not differ statistically by the Tukey test at the $5 \%$ level of significance.

Table 3. Microbiological and biochemical parameters after the fermentation 


\begin{tabular}{|c|c|c|c|c|c|c|c|c|c|c|c|c|}
\hline \multirow[b]{2}{*}{ Treatment } & \multirow[b]{2}{*}{$\begin{array}{l}\text { Total } \\
\text { bacteria }\end{array}$} & \multirow[b]{2}{*}{$\mathrm{pH}$} & \multirow[b]{2}{*}{ Glycerol } & \multirow[b]{2}{*}{ Mannitol } & \multirow[b]{2}{*}{ Sucrose } & \multirow[b]{2}{*}{ Glucose } & \multirow[b]{2}{*}{ Fructose } & \multicolumn{3}{|c|}{ Produced during the fermentation } & \multirow[b]{2}{*}{ Yield } & \multirow[b]{2}{*}{$\begin{array}{l}\text { Yeast } \\
\text { viability }\end{array}$} \\
\hline & & & & & & & & $\begin{array}{l}\text { Alcohol } \\
\text { Content }\end{array}$ & $\begin{array}{l}\text { Yeast } \\
\text { biomass }\end{array}$ & Productivity & & \\
\hline & $\begin{array}{l}\log \\
(\mathrm{CFU} \\
\left.\mathrm{ml}^{-1}+1\right)\end{array}$ & & & & $\mathrm{g} \mathrm{l}^{-1}$ & & & $\mathrm{~m} \mathrm{~m}^{-1}$ & $\mathrm{~g} \mathrm{ml}^{-1}$ & $\mathrm{gl}^{-1} \mathrm{~h}^{-1}$ & $\%$ & $\%$ \\
\hline Control & $\begin{array}{l}5.55 \pm \\
0.37^{a}\end{array}$ & $\begin{array}{l}4.38 \pm \\
0.06^{\mathrm{cb}}\end{array}$ & $\begin{array}{l}15.37 \pm \\
0.67^{a}\end{array}$ & $\begin{array}{l}0.41 \pm \\
0.02^{a}\end{array}$ & $<$ LoQ & $\begin{array}{l}0.26 \pm \\
0.02^{\mathrm{a}}\end{array}$ & $\begin{array}{l}0.09 \pm \\
0.02^{\mathrm{a}}\end{array}$ & $\begin{array}{l}6.82 \pm \\
0.19^{c}\end{array}$ & $\begin{array}{l}0.14 \pm \\
0.01^{\mathrm{a}}\end{array}$ & $\begin{array}{l}0.85 \pm \\
0.02^{\mathrm{ac}}\end{array}$ & $\begin{array}{l}88 \pm \\
2^{c}\end{array}$ & $81 \pm 2^{a}$ \\
\hline 10 kGy & $\begin{array}{l}2.68 \pm \\
0.40^{\mathrm{b}}\end{array}$ & $\begin{array}{l}4.44 \pm \\
0.11^{b}\end{array}$ & $\begin{array}{l}15.64 \pm \\
0.25^{a}\end{array}$ & $\begin{array}{l}0.39 \pm \\
0.01^{\mathrm{ab}}\end{array}$ & $<$ LoQ & $\begin{array}{l}0.25 \pm \\
0.07^{a}\end{array}$ & $\begin{array}{l}0.12 \pm \\
0.02^{\mathrm{a}}\end{array}$ & $\begin{array}{l}7.10 \pm \\
0.13^{\mathrm{ab}}\end{array}$ & $\begin{array}{l}0.15 \pm \\
0.00^{\mathrm{a}}\end{array}$ & $\begin{array}{l}0.89 \pm \\
0.02^{\mathrm{ab}}\end{array}$ & $\begin{array}{l}92 \pm \\
2^{b}\end{array}$ & $80 \pm 2^{a}$ \\
\hline 20 kGy & $\begin{array}{l}2.25 \pm \\
0.05^{b}\end{array}$ & $\begin{array}{l}4.27 \pm \\
0.02^{c}\end{array}$ & $\begin{array}{l}15.83 \pm \\
0.52^{a}\end{array}$ & $\begin{array}{l}0.37 \pm \\
0.02^{\mathrm{ab}}\end{array}$ & $<$ LoQ & $\begin{array}{l}0.48 \pm \\
0.28^{a}\end{array}$ & $\begin{array}{l}0.14 \pm \\
0.04^{\mathrm{a}}\end{array}$ & $\begin{array}{l}7.09 \pm \\
0.04^{\mathrm{ab}}\end{array}$ & $\begin{array}{l}0.15 \pm \\
0.00^{\mathrm{a}}\end{array}$ & $\begin{array}{l}0.89 \pm \\
0.01^{\mathrm{ab}}\end{array}$ & $\begin{array}{l}93 \pm \\
1^{\mathrm{ab}}\end{array}$ & $79 \pm 2^{a}$ \\
\hline 40 kGy & $\begin{array}{l}2.60 \pm \\
0.49^{b}\end{array}$ & $\begin{array}{l}4.58 \pm \\
0.05^{a}\end{array}$ & $\begin{array}{l}15.91 \pm \\
0.31^{\mathrm{a}}\end{array}$ & $\begin{array}{l}0.33^{ \pm} \\
0.03^{b}\end{array}$ & $<$ LoQ & $\begin{array}{l}0.51 \pm \\
0.44^{a}\end{array}$ & $\begin{array}{l}0.12 \pm \\
0.01^{a}\end{array}$ & $\begin{array}{l}6.96 \pm \\
0.13^{\mathrm{bc}}\end{array}$ & $\begin{array}{l}0.16 \pm \\
0.02^{a}\end{array}$ & $\begin{array}{l}0.87 \pm \\
0.02^{\mathrm{bc}}\end{array}$ & $\begin{array}{l}93 \pm \\
2^{\mathrm{ab}}\end{array}$ & $81 \pm 2^{a}$ \\
\hline Steam & $\begin{array}{l}2.20 \pm \\
0.15^{b}\end{array}$ & $\begin{array}{l}4.65 \pm \\
0.05^{a}\end{array}$ & $\begin{array}{l}15.65 \pm \\
0.20^{a}\end{array}$ & $\begin{array}{l}0.35 \pm \\
0.08^{a b}\end{array}$ & $<$ LoQ & $\begin{array}{l}0.28 \pm \\
0.17^{a}\end{array}$ & $\begin{array}{l}0.09 \pm \\
0.03^{a}\end{array}$ & $\begin{array}{l}7.28 \pm \\
0.04^{a}\end{array}$ & $\begin{array}{l}0.14 \pm \\
0.00^{\mathrm{a}}\end{array}$ & $\begin{array}{l}0.91 \pm \\
0.00^{\mathrm{a}}\end{array}$ & $\begin{array}{l}95 \pm \\
0^{a}\end{array}$ & $82 \pm 2^{a}$ \\
\hline CV & 10.88 & 1.43 & 2.74 & 10.70 & 0 & 7.68 & 22.22 & 1.73 & 5.85 & 1.73 & 1.72 & 2.79 \\
\hline
\end{tabular}

CFU: Colony Forming Unit, <LoQ: Lower than Limit of Quantitation, CV: coefficient of variation. Averages of $n=5 \pm$ standard deviation. Superscript equal letters in the same column do not differ statistically by the Tukey test at the $5 \%$ level of significance.

Table 4. Operating cost relative to the use of electron beam for different doses of radiation applied to sugarcane molasses wort

\begin{tabular}{|llll|}
\hline Treatment & Radiation dose (kGy) & $\Delta \mathrm{t}(\mathrm{s})$ & Cost (US\$) \\
\hline T0 & 0 & 0 & 0 \\
\hline T1 & 10 & 11,6 & 0,644 \\
\hline T2 & 20 & 23,2 & 0,128 \\
\hline T3 & 40 & 46,4 & 0,258 \\
\hline T4 & 80 & 92,8 & 0,515 \\
\hline
\end{tabular}

Figures
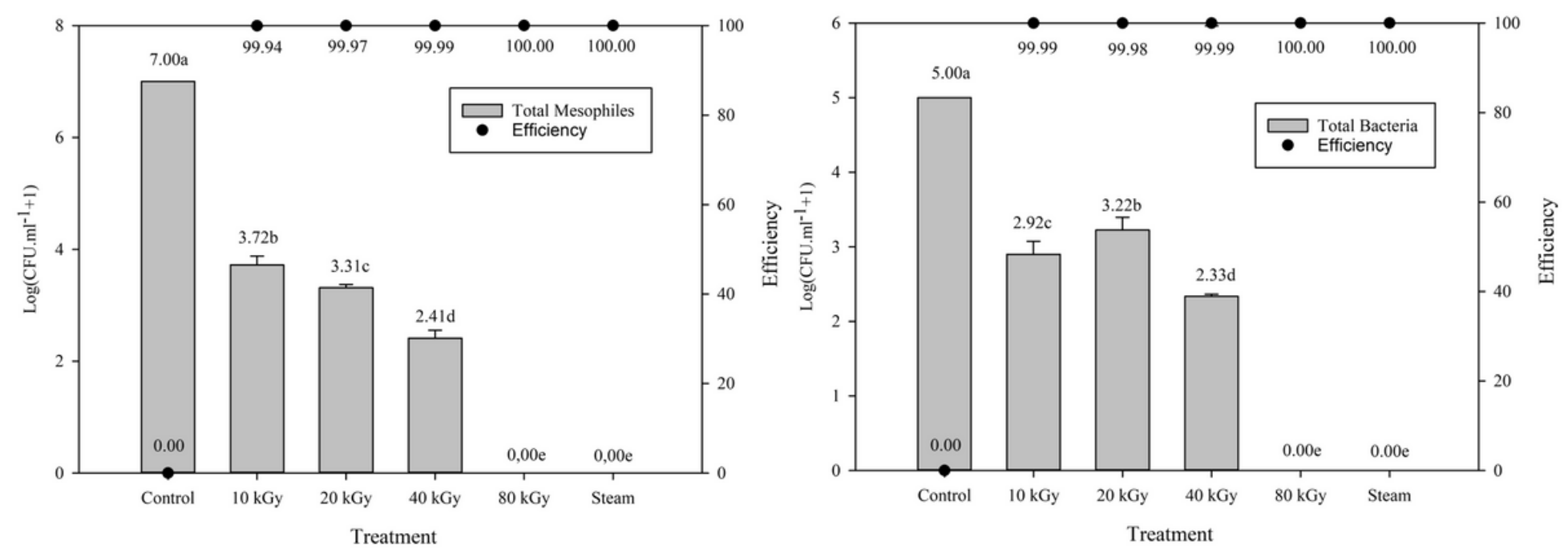

Figure 1

Total mesophiles and total bacteria in sugarcane molasses wort after electron beam irradiation treatment in different doses The error bars represent the standard deviation 

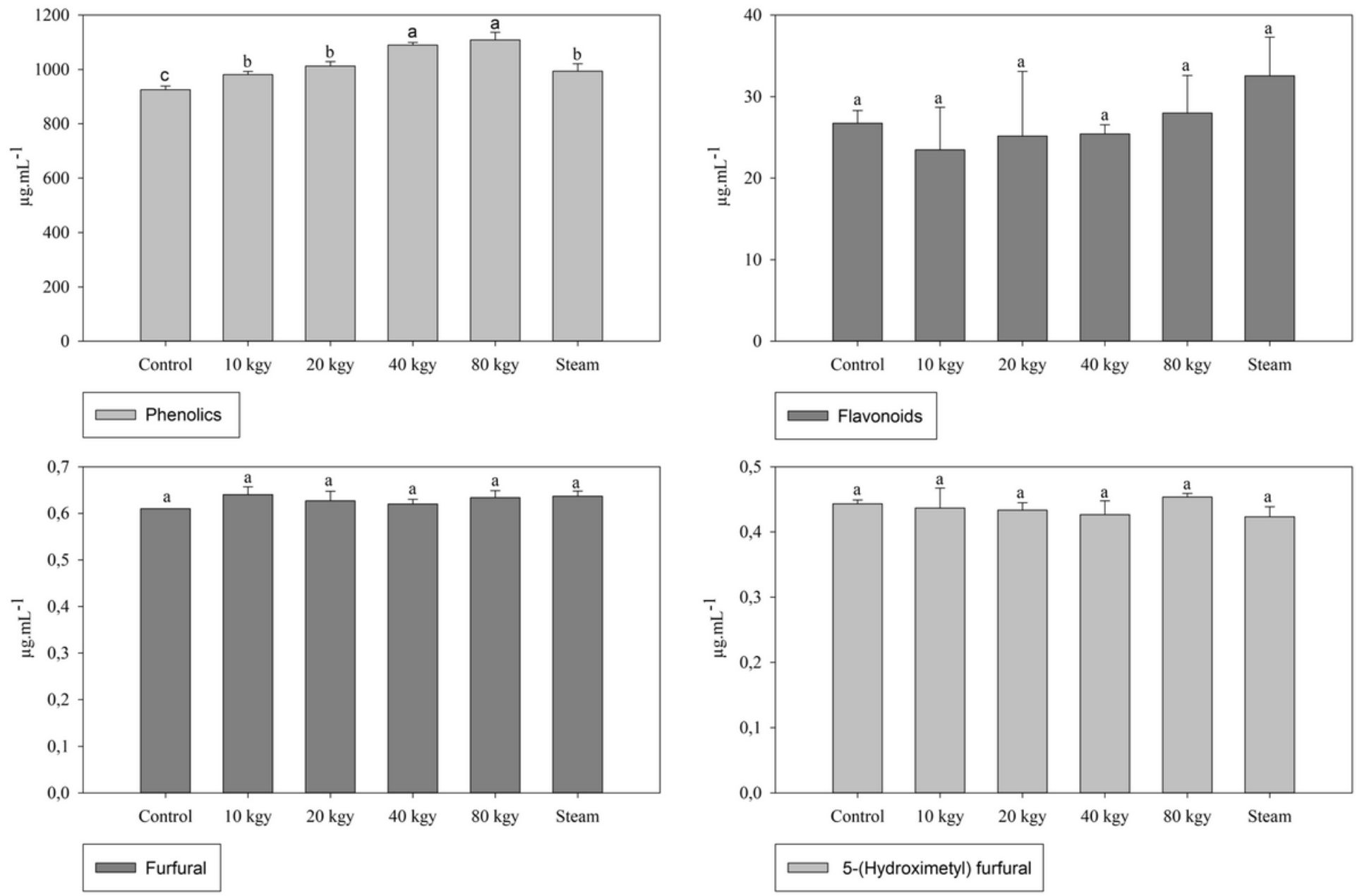

Figure 2

Inhibitors concentrations in sugarcane molasses wort after treatments The error bars represent the standard deviation

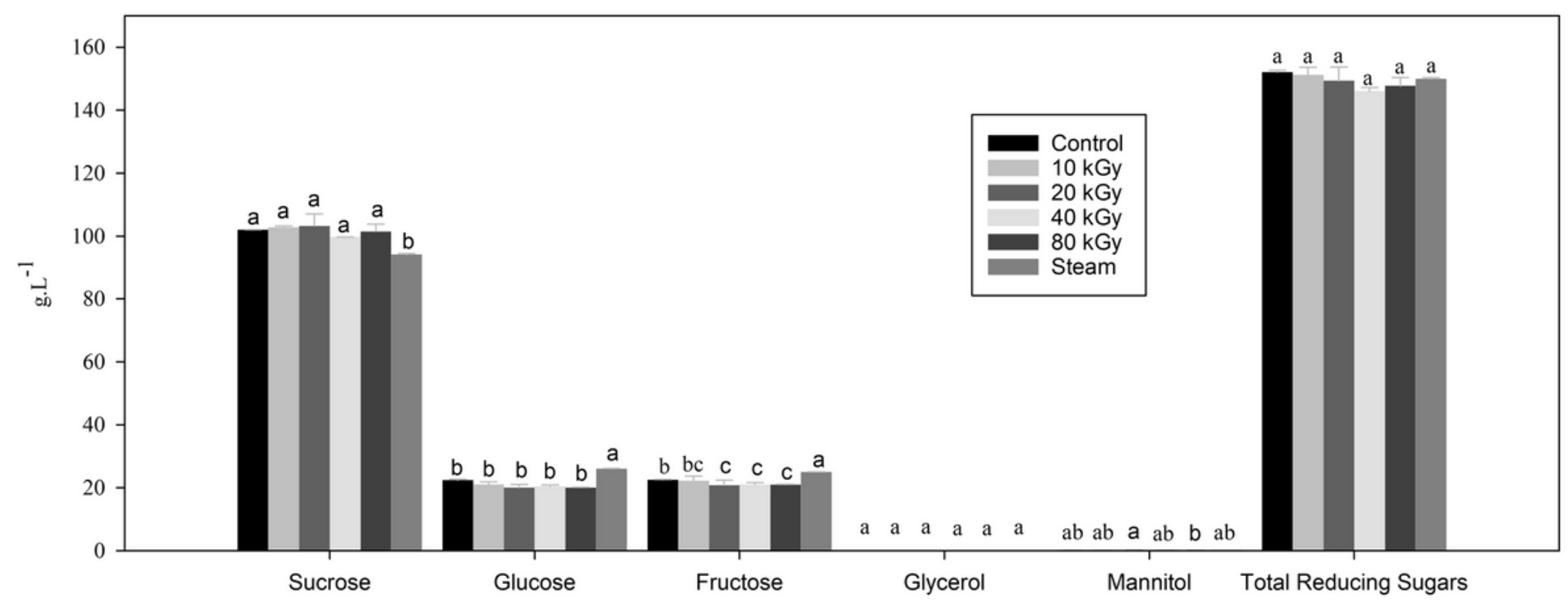

Figure 3

Sugars concentrations at the start of fermentation The error bars represent the standard deviation 